\title{
DAMPAK COVID-19 PADA PEMBELAJARAN PENDIDIKAN JASMANI OLAHRAGA DAN KESEHATAN SMP DI PROVINSI KEPULAUAN BANGKA BELITUNG
}

\author{
Muhammad Eka Mardyansyah Simbolon ${ }^{1}$, Karmila Sari ${ }^{2}$, Dexa Egi Nassandi ${ }^{3}$, Malpino \\ Andre Saputra ${ }^{4}$, Joko Supriyanto ${ }^{5}$
}

Fakultas Keguruan dan Ilmu Pendidikan

Universitas Muhammadiyah Bangka Belitung ${ }^{1}$

Email: karmilasari170814@gmail.com

\begin{abstract}
ABSTRAK
Penelitian ini bertujuan untuk mengetahui dampak covid-19 pada pembelajaran PJOK Sekolah Menengah Pertama di Provinsi Kepulauan Bangka Belitung. Penelitian ini adalah penelitian kuantitatif deskriptif. Alat ukur yang digunakan dalam penelitian ini adalah kuesioner. Responden dalam penelitian ini yaitu 17 orang guru PJOK, 296 orang siswa, dan 214 orang tua. Responden mengisi angket yang terdiri dari 15 butir pertanyaan dengan memberi tanda centang pada kolom yang telah disediakan. Penelitian ini menggunakan metode survei dan dianalisis secara deskriptif kuantitatif. Berdasarkan hasil penelitian maka disimpulkan bahwa selama pandemi covid-19 pelaksanaan pembelajaran PJOK Sekolah Menengah Pertama di Provinsi Kepulauan Bangka Belitung dilaksanakan secara daring. Pembelajaran daring selama pandemi covid-19 secara keseluruhan sudah baik. Maka dari itu pembelajaran dapat dilaksanakan secara daring selama kondisi pandemi sampai batas waktu yang ditentukan oleh Pemerintah.
\end{abstract}

Kata Kunci: bangka belitung; covid-19; pembelajaran; pjok

\section{ABSTRACT}

This study aims to determine the impact of covid-19 on learning PJOK for Junior High Schools in the Province of Bangka Belitung Islands. This research is a descriptive quantitative research. The measuring instrument used in this research is a questionnaire. Respondents in this study were 17 PJOK teachers, 296 students, and 214 parents. Respondents filled out a questionnaire consisting of 15 questions by placing a check mark in the column provided. This study used a survey method and was analyzed descriptively quantitatively. Based on the results of the study, it was concluded that during the Covid-19 pandemic the implementation of PJOK for Junior High Schools in Bangka Belitung Islands Province was carried out online. Online learning during the Covid-19 pandemic has been overall good. Therefore, learning can be carried out online during pandemic conditions until the time limit determined by the Government.

Keywords: bangka belitung; covd-19; learning; pjok

Dipublikasikan Oleh :

UPT Publikasi dan Pengelolaan Jurnal

Universitas Islam Kalimantan Muhammad Arsyad Al-Banjari Banjarmasin 


\section{PENDAHULUAN}

Dunia sedang menghadapi ancaman serius virus corona atau covid-19 yang pertama kali menyebar pada Desember 2019 dari kota Wuhan, China. Covid-19 adalah virus mematikan yang menyerang sistem pernapasan manusia dan ditularkan melalui percikan air liur (tetesan). Menurut data Kementerian Kesehatan, sebanyak 215 negara telah terjangkit Covid-19, termasuk Indonesia. Pada 2 Maret 2020, kasus pertama Covid-19 ditemukan di Indonesia pada wanita berusia 31 tahun dan 64 tahun yang merupakan anak-anak dan orang tua. (Dyah Purnama Sari, 2020). Infeksi virus corona pertama kali ditemukan di China pada 8 Desember 2019. China tercatat sebagai negara yang pertama kali melaporkan kasus Covid-19 di dunia. (Engko \& Usmany, 2020)

Manusia merupakan mahluk sosial yang memungkinkan saling berinteraksi secara langsung sehingga tingkat penyebaran pandemi Covid-19 semakin pesat. Sehingga Pemerintah tengah menyiapkan aturan karantina kewilayahan atau lockdown untuk memutuskan mata rantai penyebaran virus corona.(Siahaan, 2020). Selain sektor ekonomi, transportasi dan pertanian, pandemi Covid-19 juga membawa pengaruh bagi dunia pendidikan. Dampak penyebaran Covid-19 kini mulai memasuki dunia pendidikan. Institusi-institusi pendidikan diharapkan untuk tidak melaksanakan kegiatan seperti biasanya; hal ini diharapkan untuk mengurangi penyebaran covid-19. (Firman, 2020)

Organisasi Kesehatan Internasional (WHO) mengumumkan status virus Covid-19 sebagai pandemi yang mengharuskan seluruh dunia untuk segera melakukan upaya untuk menghentikan serta mengatasi dampak yang ditimbulkannya. Cara yang dipilih pemerintah untuk menekan penyebaran virus di Indonesia adalah physical distancing. Pembatasan menimbulkan banyak perubahan dalam berbagai aspek kehidupan sosial, ekonomi, budaya, bahkan pendidikan.(Dyah Purnama Sari, 2020)

Kemendikbud RI mengeluarkan Surat Edaran Menteri Pendidikan Nomor 4 Tahun 2020 tentang Penyelenggaraan Kebijakan dan Edukasi dalam Masa Darurat Penyebaran Corona Virus Disease (Covid-19) dengan mencairkan dan mengganti proses Kegiatan Belajar Mengajar di sekolah dengan menggunakan sistem online di rumah. Physical distancing (pembatasan interaksi) merupakan salah satu cara memutus rantai penyebaran Covid-19, yaitu dengan pembatasan interaksi masyarakat.(Wijayanto et al., 2020)

Dunia pendidikan ikut merasakan dampak dari adanya pandemi Covid-19. Adanya pandemi Covid-19 membuat pembelajaran tatap muka secara konvensional tidak mungkin lagi dilakukan di berbagai daerah. Menurut Undang-Undang Nomor 20 Tahun 2003 tentang Sistem Pendidikan Nasional Bab I Pasal I Pasal 1 (ayat 1), pendidikan pada dasarnya merupakan upaya sadar dan terencana untuk mewujudkan suasana proses pembelajaran dan pembelajaran sehingga peserta didik aktif mengembangkan potensinya untuk memiliki kekuatan spiritual keagamaan, pengendalian diri, kepribadian, kecerdasan, akhlak mulia, serta keterampilan yang diperlukan dari diri mereka sendiri, masyarakat, bangsa, dan negara. Pendidikan merupakan usaha sadar dan terencana untuk memberikan bimbingan dan pertolongan dalam mengembangkan potensi anak baik jasmani ataupun rohani yang dimana di berikan oleh orang dewasa kepada anak untuk mencapai kedewasaannya serta mencapai tujuan anak menjadi manusia yang beriman, berakhlak mulia, berilmu, kreatif dan mandiri yang dapat di terima di dalam masyarakat. Pendidikan akan memberikan pengalaman-pengalaman belajar di dalam program-program pendidikan formal, nonformal atau informal di sekolah. (Pratama \& Mulyati, 2020)

Dampak covid-19 terhadap dunia pendidikan sangat besar dan dirasakan oleh berbagai pihak terutama guru, kepala sekolah, peserta didik dan orang tua. Akibat penyebaran covid-19 yang tinggi di Indonesia, universitas dan perguruan tinggi lainnya ditutup tidak terkecuali sekolah dasar. Dengan dilakukannya penutupan sekolah, maka pemerintah mengambil langkah agar proses pembelajaran tidak tertinggal dan peserta didik tetap menerima hak mereka untuk mendapatkan ilmu. Maka dari itu keputusan pemerintah selanjutnya yaitu proses pembelajaran tetap berlangsung tapi tidak dengan tatp muka melainkan dengan online.(Mastura \& Santaria, 2020)

Covid-19 telah mengubah gaya hidup orang di seluruh dunia, orang-orang disarankan untuk menjaga jarak dan membatasi perjalanan sesering mungkin dan langkah-langkah keamanan ini juga berlaku untuk dunia pendidikan. Di Jerman, semua sekolah mengalami penutupan hingga 20 April 2020. Pemerintah negara bagian tersebut telah merekomendasikan untuk pembelajaran online dan materi pembelajaran tambahan melalui sistem online. (Handayani, 2020). Tidak lepas dari pengalaman dan sejarah mengenai virus Ebola yang pernah terjadi di beberapa negara khususnya Afrika. Covid-19 juga diprediksi juga akan meninggalkan beberapa masalah yang sama dengan virus-virus sebelumnya. Hal tersebut harus cepat diatasi untuk mengurangi dampak depresi atau bahkan kembali meningkatkan minat belajar untuk para siswa. Jangan sampai dampak dari Covid 19 tidak diperhatikan dan dibiarkan begitu saja atau bahkan lambat dalam penanganannya. (Marheni et al., 2020)

Di Inggris, meskipun pemerintah tidak mengeluarkan pedoman bersama untuk pendidikan online sebagai tanggapan terhadap pandemi Covid-19, pendidikan online telah dilaksanakan di sekolah-sekolah tertentu tergantung pada status mereka. Setelah kasus pertama COVID-19 di Korea Selatan, Kementerian Pendidikan

\section{Dipublikasikan Oleh :}

UPT Publikasi dan Pengelolaan Jurnal

Universitas Islam Kalimantan Muhammad Arsyad Al-Banjari Banjarmasin 
setempat menunda awal tahun sekolah empat kali, dan sejak saat itu mereka telah menerapkan pendekatan online bertahap untuk awal semester. Banyak perguruan tinggi di Cina telah memutuskan untuk membatalkan kelas tatap muka dan menerapkan pembelajaran online untuk keselamatan siswa dan fakultas.(Handayani, 2020)

Di Korea Selatan, perguruan tinggi membatalkan awal program yang dijadwalkan akan dimulai pada 2 Maret 2020, dan telah memilih untuk melanjutkan pembelajaran online. Tenaga administrasi sekolah, pengajar, dan siswa melakukan upaya dalam berbagai cara untuk menyesuaikan diri dengan lingkungan pembelajaran online yang baru. Implementasi pembelajaran online tidak terbatas pada situasi krisis seperti pandemi saat ini, pembelajaran online telah disarankan sebagai pengganti pembelajaran tatap muka).(Handayani, 2020)

Belum meredanya wabah virus corona di Indonesia, memaksa pemerintah memperpanjang masa belajar -mengajar dari rumah hingga waktu yang tidak ditentukan. Tak berarti libur dari aktivitas belajar mengajar, semua sekolah diwajibkan menggunakan pembelajaran di rumah secara online dan secara manual. Instruksi belajar dari rumah yang dikeluarkan oleh pemerintah pusat, tak sepenuhnya berjalan lancar. (Herliandry et al., 2020). Sekolah dituntut tetap mampu memberikan layanan standar minimum kepada pemangku kepentingannya di tengah Work From Home (WFH) dan Pembatasan Sosial Berskala Besar (PSBB) (Ali Murfi, dkk., 2020: 121). Pembelajaran daring menjadi salah satu alternatif dalam mengatasi permasalahan tersebut (Ali Sadikin, 2020). Pembelajaran secara daring merupakan solusi untuk melaksanakan pembelajaran meskipun pendidik dan peserta didik berada pada lokasi yang berbeda. Hal ini mampu menjadi solusi supaya peserta didik tetap dapat mengikuti proses pempelajaran yang diberikan. (Ekantini, 2020)

Sebagai upaya untuk mencegah dan melindungi guru maupun siswa, beberapa pihak berwenang menetapkan kebijakan WFH untuk sementara waktu (Harususilo, 2020), (Pahan \& Fitriani, 2020). Dalam hal ini pendidik dan siswa diharuskan untuk belajar secara online dan menjalankan social distancing selama terjadinya wabah corona ini guna untuk memutus jaringan virus tersebut. (Ainur Risalah et al., 2020). Proses pembelajaran di sekolah merupakan alat kebijakan publik terbaik sebagai upaya peningkatan pengetahuan dan skill. Selain itu banyak siswa menganggap bahwa sekolah adalah kegiatan yang sangat menyenangkan, mereka bisa berinteraksi dengan teman. Sekolah dapat meningkatkan keterampilan sosial dan kesadaran kelas sosial siswa.(Syah, 2020)

Proses pembelajaran sebagai sesuatu yang dialami siswa di sekolah sendiri merupakan alat kebijakan publik terbaik sebagai upaya peningkatan pengetahuan dan skill. Hal yang kemudian juga telah tertanam dalam diri sebagian besar peserta didik adalah sekolah menjadi tempat yang menyenangkan sebagai wahana bermain, berinteraksi dan membangun hubungan serta kesadaran sosial. Sekolah pula menjadi pusat interaksi antara guru dengan peserta didik dalam meningkatkan, pengetahuan, keterampilan serta penanaman sikap dan karakter mereka, maka hal tersebutlah yang kemudian tiba-tiba berhenti saat sekolah pun tiba-tiba ditutup. (Saleh, 2020)

Pembelajaran secara daring di masa pandemi Covid-19 dikukuhkan dengan Surat Edaran Mendikbud No.4 tahun 2020 tentang pelaksanaan kebijakan Pendidikan dalam masa darurat penyebaran covid-19. Dalam surat edaran tersebut dinyatakan bahwa satuan pendidikan yang berasa pada daerah zona kuning, oranye, dan merah dilarang melaksanakan proses pembelajaran secara tatap muka dan tetap melaksanakan pembelajaran di rumah secara daring. (Ekantini, 2020)

Berdasarkan survey yang dilakukan kepada 38 peserta didik kelas VIII SMP Muhammadiyah 1 Jetis terkait berbagai aplikasi pembelajaran yang memungkinkan untuk digunakan, didapatkan data bahwa $90 \%$ siswa hanya familier dengan aplikasi whatsapp, sedangkan $10 \%$ yang lain familier dengan whatsapp dan berbagai aplikasi lain seperti google classroom dan telegram. Berdasarkan hasil survey ini, maka pembelajaran daring pada mata pelajaran IPA kelas VIII SMP Muhammadiyah 1 Jetis menggunakan aplikasi Whatsapp. (Ekantini, 2020). Proses pembelajaran IPA yang menekankan pada pemberian pengalaman langsung untuk mengembangkan kompetensi agar menjelajahi dan memahami alam sekitar secara ilmiah (Chan, 2017). Salah satu ilustrasi yang mampu memberikan informasi penjelasan kepada peserta didik ialah demontrasi (Fatimah, 2017). Berdasarkan hal tersebut, guru menggunakan whatsapp sebagai aplikasi pembelajaran online dengan dibantu video demontrasi pada beberapa materi yang membutuhkan praktik. Materi pembelajaran diberikan guru kepada peserta didik melalui aplikasi whatsapp dalam bentuk powerpoint, materi bacaan, dan video demontrasi singkat. (Ekantini, 2020)

Penyebaran pandemi Covid-19 yang cepat telah menyebabkan terjadinya gangguan pada sektor pendidikan Indonesia di mana sekitar 45 juta siswa tidak dapat melanjutkan kegiatan belajar mereka di sekolah. Dunia pendidikan tidak akan pernah terlepas dari proses pembelajaran. Pembelajaran dengan kata dasar belajar sebenarnya merupakan proses yang mencakup dua hal yaitu belajar dan mengajar. Kegiatan belajar biasanya difokuskan pada kegiatan siswa dalam pendidikan. Sedangkan mengajar biasanya difokuskan pada kegiatan guru dalam pembelajaran. Meski dewasa ini, kegiatan belajar dan mengajar dapat dilakukan oleh semua pelaku pendidikan tidak hanya guru dan siswa saja. Pembelajaran yang mencakup kedua hal di atas.(Rochman et al., 2020)

Dipublikasikan Oleh :

UPT Publikasi dan Pengelolaan Jurnal

Universitas Islam Kalimantan Muhammad Arsyad Al-Banjari Banjarmasin 
Dimyati \& Mudjiono (2002) mengartikan pembelajaran sebagai kegiatan guru secara terprogram dalam desain instruksional dengan tujuan agar siswa belajar secara aktif, yang menekankan kepada penyediaan sumber belajar. Pendapat yang dikemukakan di atas secara tidak langsung mengartikan pembelajaran sebagai fasilitas yang digunakan oleh guru untuk membuat siswa belajar secara mandiri. Sedangkan menurut Saiful (2006), pembelajaran diartikan sebagai interaksi belajar mengajar yang mengacu pada suatu tujuan tertentu yang telah dirumuskan pada satuan pelajaran atau silabus. Pendapat ini menekankan pada proses yang terjadi dalam pembelajaran yaitu interaksi belajar mengajar. (Rochman et al., 2020)

Pembelajaran merupakan inti dari proses pendidikan. Kualitas pendidikan menggambarkan kualitas pembelajaran. Peningkatan kualitas pendidikan dapat dilakukan melalui peningkatan kualitas pembelajaran.(Argaheni, 2020). Pembelajaran tidak selamanya berjalan dengan baik sesuai rencana yang telah disusun. Tujuan pembelajaran tidak selamanya dicapai secara maksimal karena dinamika pembelajaran yang dipengaruhi oleh banyak faktor. Situasi ini tentunya mempengaruhi aspek kognitif, psikomotorik dan afektif peserta didik berkembang dengan lamban. Saat ini, dunia yang dilanda Covid-19 secara masal menjadi faktor eksternal baru yang berpengaruh pada penyelenggaraan pendidikan di Indonesia. (Mansyur, 2020)

Hakikat pembelajaran PJOK yang syarat dengan gerakan fisik, pembelajarannya dilakukan di ruang terbuka atau di lapangan. Metode untuk pendidikan olahraga adalah metode deduktif atau metode perintah, dengan ragam pemberian tugas, demonstrasi dan sedikit penjelasan.(Herlina \& Suherman, 2020). Dalam kondisi pandemi terjadi perubahan sistem pembelajaran secara keseluruhan. Pendidikan Olahraga atau yang lebih dikenal dengan Pendidikan Jasmani, Olahraga dan Kesehatan, merupakan matapelajaran yang memiliki ciri khas gerak tubuh sebagai media utama pembelajaran. Tujuan dari pendidikan jasmani, olahraga dan kesehatan, tergolong kompleks, karena bukan hanya melibatkan aktifitas tubuh saja, namun juga terdapat proses rangsangan neuromuscular dalam menguasai gerakan tertentu, selain itu juga pada pembelajaran pendidikan jasmani bukan hanya dituntut aktif bergerak, namun juga aktif berfikir (terutama dalam memahami gerak dan mengambil keputusan saat praktik berlomba atau bertanding) juga harus peka terhadap lingkungan sosialnya, terutama yang berhubungan dengan aktifitas teamwork. Oleh karena itulah maka tujuan pendidikan jasmani menjadi kompleks dan masing-masing aspek harus dikembangkan secara harmonis.(Wijayanto et al., 2020)

Berdasarkan latar belakang masalah maka tujuan penelitian ini adalah untuk mengetahui dampak covid19 pada pembelajaran Pendidikan Jasmani Olahraga dan Kesehatan SMP di Provinsi kepulauan Bangka Belitung.

\section{METODE}

Penelitian jenis ini merupakan kajian kuantitatif deskriptif untuk mengetahui dampak covid-19 pada pembelajaran Pendidikan Jasmani Olahraga dan Kesehatan SMP di Provinsi kepulauan Bangka belitung. Dalam penelitian ini hanya ada satu variabel tanpa membuat perbandingan dengan variabel lainnya. Variabel dalam penelitian ini adalah dampak covid-19 pada pembelajaran Pendidikan Jasmani Olahraga dan Kesehatan SMP di Provinsi kepulauan Bangka belitung. Responden dalam penelitian ini adalah siswa SMP, orang tua, dan guru Pendidikan Jasmani Olahraga dan Kesehatan di Kepulauan Bangka Belitung yang berjumlah siswa SMP sebanyak 296 orang, orang tua sebanyak 214 orang, dan guru PJOK sebanyak 17 orang. Teknik yang digunakan dalam penelitian ini adalah teknik Simple Random Sampling. Data dianalisis menggunakan statistik deskriptif dengan bantuan komputerisasi.

Tabel.1 Sebaran Responden

\begin{tabular}{lcccc}
\hline & Guru & Orang tua & Siswa & Keseluruhan \\
\hline Laki & 17 orang & 117 orang & 163 orang & 297 orang \\
Perempuan & 0 orang & 97 orang & 133 orang & 230 orang \\
Bangka & 8 orang & 20 orang & 51 orang & 79 orang \\
Bangka Tengah & 0 orang & 7 orang & 9 orang & 16 orang \\
Bangka Barat & 7 orang & 3 orang & 19 orang & 29 orang \\
Bangka Selatan & 1 orang & 168 orang & 195 orang & 364 orang \\
Pangkal Pinang & 1 orang & 16 orang & 22 orang & 39 orang \\
\hline
\end{tabular}

Sebaran responden penelitian ini berdasarkan tabel yaitu 17 orang guru laki-laki, 117 orang tua lakilaki, 97 orang tua perempuan, 163 orang siswa laki-laki, dan 133 orang siswa perempuan yang tersebar di Kabupaten yang ada di Provinsi Kepulauan Bangka Belitung. Jadi jumlah keseluruhan dari responden dalam penelitian ini sebanyak 527 orang.

Dipublikasikan Oleh :

UPT Publikasi dan Pengelolaan Jurnal

Universitas Islam Kalimantan Muhammad Arsyad Al-Banjari Banjarmasin 


\section{Prosedur Penelitian}

Agar proses penelitian pada metode penelitian deskriptif kuantitatif lebih terarah, sehingga di buat desain penelitian, untuk desain penelitian yang diterapkan dalam penelitian ini yaitu menggunakan penilaian data angket. Dimana setiap siswa/siswi, orang tua, guru PJOK mengisi setiap butir soal yang berada di dalam angket tersebut. Desain penelitiannya dapat dilihat sebagai berikut :

- Menyebarkan angket kepada siswa/siswi

- Menyebarkan angket kepada orang tua murid

- Menyebarkan angket kepada guru Pendidikan Jasmani Olahraga dan Kesehatan

Untuk prosedur ini dilakukan sebanyak satu kali dan wajib mengisi semua butir soal yang berada dalam angket.

\section{Instrumen Penelitian}

Instrumen penelitian yan digunakan dalam penelitian ini berupa angket yang terdiri dari 15 butir pertanyaan yang bertujuan mengungkapkan dampak covid-19 pada pembelajaran Pendidikan Jasmani Olahraga dan Kesehatan SMP di Provinsi kepulauan Bangka Belitung. Angket yang digunakan berupa angket tertutup. Berikut 15 butir pertanyaan tersebut. Angket tertutup adalah angket yang disajikan dalam bentuk sedemikian rupa sehingga responden tinggal memberikan tanda centang (v) pada kolom atau tempat yang sesuai. (Firman, 2020)

Tabel.2 Butir Pertanyaan Angket

\begin{tabular}{ll}
\hline No & \multicolumn{1}{c}{ Pertanyaan } \\
\hline 1. & Selama masa pandemi covid-19, kegiatan belajar mengajar secara : \\
2. & Apakah kesulitan dalam pelaksanaan kegiatan belajar mengajar selama masa pandemi? \\
3. & Apakah ada bantuan khusus dari sekolah selama pembelajaran dimasa pandemi? \\
4. & Apakah ada media seperti gadget yang mendukung kegiatan pembelajaran dimasa pandemi? \\
5. & Apakah materi pembelajaran disesuaikan dengan kondisi pandemi? \\
6. & Apakah terdapat kesulitan dalam pengumpulan tugas yang diberikan saat masa pandemi? \\
7. & Apakah terdapat kesesuaian dalam pemberian nilai pada masa pandemi? \\
8. & Bagaimana kesiapan saat menghadapi pembelajaran di masa pandemi? \\
9. & Apakah media yang digunakan sudah efektif selama pembelajaran berlangsung? \\
10. & Apakah materi yang disampaikan bisa dipahami dengan mudah? \\
11. & Apakah proses pembelajaran dapat disesuaikan dengan tujuan? \\
12. & Apakah terdapat perubahan jadwal pembelajaran selama masa pandemi? \\
13. & Apakah ekonomi berpengaruh pada pembelajaran saat pandemi? \\
14. & Apakah ada pemantauan terhadap pelaksanaan pembelajaran selama pandemi? \\
15. & Bagaimana persepsi saudara terhadap kegiatan belajar mengajar selama pandemi? \\
\hline
\end{tabular}

\section{HASIL DAN PEMBAHASAN}

Penyebaran angket penelitian ini dilaksanakan dalam kurun waktu 21 hari. Hasil penyebarannya mengumpulkan sebanyak 527 responden. Respondennya yaitu terdiri dari peserta didik Sekolah Menengah Pertama, orang tua dan guru Pendidikan Jasmani Olahraga dan Kesehatan yang ada di Kepulauan Bangka Belitung.

Tabel 3. Butir Pertanyaan Angket

\begin{tabular}{clcccccccc}
\hline & & \multicolumn{2}{c}{ Keseluruhan } & \multicolumn{2}{c}{ Guru } & \multicolumn{2}{c}{ Siswa } & \multicolumn{2}{c}{ Orang tua } \\
Data angket & & $\Sigma$ & $\%$ & $\Sigma$ & $\%$ & $\Sigma$ & $\%$ & $\Sigma$ & $\%$ \\
\hline Butir 1 & Daring & 288 & 54,7 & 17 & 100 & 163 & 55,1 & 108 & 50,5 \\
& Luring & 133 & 25,2 & 0 & 0 & 79 & 26,7 & 54 & 25,2 \\
& Gabungan & 106 & 20,1 & 0 & 0 & 54 & 18,2 & 52 & 24,3 \\
Butir 2 & Ya & 431 & 81,8 & 14 & 82,4 & 241 & 81,4 & 177 & 82,7 \\
& Tidak & 96 & 18,2 & 3 & 17,6 & 55 & 18,6 & 37 & 17,3 \\
Butir 3 & Ya & 336 & 63,8 & 14 & 82,4 & 200 & 67,6 & 122 & 57,0 \\
\hline
\end{tabular}

Dipublikasikan Oleh :

UPT Publikasi dan Pengelolaan Jurnal

Universitas Islam Kalimantan Muhammad Arsyad Al-Banjari Banjarmasin 


\begin{tabular}{|c|c|c|c|c|c|c|c|c|c|}
\hline \multirow[b]{2}{*}{ Data angket } & & \multicolumn{2}{|c|}{ Keseluruhan } & \multicolumn{2}{|c|}{ Guru } & \multicolumn{2}{|c|}{ Siswa } & \multicolumn{2}{|c|}{ Orang tua } \\
\hline & & $\Sigma$ & $\%$ & $\Sigma$ & $\%$ & $\Sigma$ & $\%$ & $\Sigma$ & $\%$ \\
\hline \multirow{3}{*}{ Butir 4} & Tidak & 191 & 36,2 & 3 & 17,6 & 96 & 32,4 & 92 & 43,0 \\
\hline & $\mathrm{Ya}$ & 458 & 87,0 & 13 & 76,5 & 263 & 88,9 & 182 & 85,0 \\
\hline & Tidak & 69 & 13,0 & 4 & 23,5 & 33 & 11,1 & 32 & 15,0 \\
\hline \multirow[t]{2}{*}{ Butir 5} & $\mathrm{Ya}$ & 421 & 79,9 & 15 & 88,2 & 238 & 80,4 & 169 & 79,0 \\
\hline & Tidak & 106 & 20,1 & 2 & 11,8 & 58 & 19,6 & 45 & 21,0 \\
\hline \multirow[t]{2}{*}{ Butir 6} & Ya & 266 & 50,5 & 11 & 64,7 & 147 & 49,7 & 107 & 50,0 \\
\hline & Tidak & 261 & 49,5 & 6 & 35,3 & 149 & 50,3 & 107 & 50,0 \\
\hline \multirow[t]{2}{*}{ Butir 7} & $\mathrm{Ya}$ & 439 & 83,3 & 14 & 82,4 & 245 & 82,8 & 180 & 84,1 \\
\hline & Tidak & 88 & 16,7 & 3 & 17,6 & 51 & 17,2 & 34 & 15,9 \\
\hline \multirow[t]{3}{*}{ Butir 8} & Sangat baik & 44 & 8,3 & 2 & 11,8 & 24 & 8,1 & 18 & 8,4 \\
\hline & Baik & 276 & 52,4 & 15 & 88,2 & 157 & 53,0 & 104 & 48,6 \\
\hline & Kurang baik & 207 & 39,3 & 0 & 0 & 115 & 38,9 & 92 & 43,0 \\
\hline \multirow[t]{2}{*}{ Butir 9} & $\mathrm{Ya}$ & 344 & 65,3 & 11 & 64,7 & 206 & 69,6 & 125 & 58,4 \\
\hline & Tidak & 183 & 34,7 & 6 & 35,3 & 90 & 30,4 & 89 & 41,6 \\
\hline \multirow[t]{2}{*}{ Butir 10} & $\mathrm{Ya}$ & 221 & 42,0 & 10 & 58,8 & 136 & 45,9 & 75 & 35,0 \\
\hline & Tidak & 306 & 58,0 & 7 & 41,2 & 160 & 54,1 & 139 & 65,0 \\
\hline \multirow[t]{2}{*}{ Butir 11} & Ya & 362 & 68,7 & 11 & 64,7 & 214 & 72,3 & 137 & 64,0 \\
\hline & Tidak & 165 & 31,3 & 6 & 35,3 & 82 & 27,7 & 77 & 36,0 \\
\hline \multirow[t]{2}{*}{ Butir 12} & Ya & 407 & 77,2 & 12 & 70,6 & 225 & 76,0 & 170 & 79,4 \\
\hline & Tidak & 120 & 22,8 & 5 & 29,4 & 71 & 24,0 & 44 & 20,6 \\
\hline \multirow[t]{2}{*}{ Butir 13} & $\mathrm{Ya}$ & 402 & 76,3 & 17 & 100 & 218 & 73,6 & 171 & 80,0 \\
\hline & Tidak & 125 & 23,7 & 0 & 0 & 78 & 26,4 & 43 & 20,0 \\
\hline \multirow[t]{2}{*}{ Butir 14} & $\mathrm{Ya}$ & 329 & 62,4 & 17 & 100 & 189 & 63,9 & 125 & 58,4 \\
\hline & Tidak & 198 & 37,6 & 0 & 0 & 107 & 36,1 & 89 & 41,6 \\
\hline \multirow[t]{3}{*}{ Butir 15} & Sangat baik & 38 & 7,2 & 0 & 0 & 24 & 8,2 & 15 & 7,0 \\
\hline & Baik & 247 & 46,9 & 17 & 100 & 136 & 45,9 & 94 & 43,9 \\
\hline & Kurang baik & 242 & 45,9 & 0 & 0 & 136 & 45,9 & 105 & 49,1 \\
\hline
\end{tabular}

Berdasarkan hasil penelitian yang kami lakukan dampak covid-19 terhadap pembelajaran PJOK SMP di Provinsi Kepulauan Bangka Belitung yaitu pembelajaran yang awalnya dilakukan secara tatap muka, saat pandemi covid-19 sebanyak 54,7\% Sekolah Menengah Pertama di Bangka Belitung melakukan pembelajaran secara daring/online, sebanyak 25,2\% melakukan pembelajaran secara luring, dan 20,1\% melakukan pembelajaran secara gabungan. Berkaitan dengan adanya wabah Covid-19 di Indonesia, pembelajaran di Indonesia bergeser dari yang awalnya melakukan pembelajaran secara tatap muka, kemudian menjadi pembelajaran jarak jauh dengan memanfaatkan teknologi. Pembelajaran jarak jauh di Indonesia diatur dalam Surat Edaran Kementerian Pendidikan dan Kebudayaan Nomor 4 Tahun 2020 mengenai Pelaksanaan Pendidikan Dalam Masa Darurat Covid-19. Dalam Surat Edaran tersebut terdapat tiga poin yang menjelaskan kebijakan pembelajaran jarak jauh secara online, yaitu: pembelajaran jarak jauh dilakukan untuk memberikan pengalaman belajar yang baru dan bermakna, tanpa memberikan beban untuk menuntut siswa menyelesaikan capaian kurikulum untuk dapat melaksanakan kegiatan belajar mengajar selama wabah Covid-19, menurut BPS (dalam Arfiansyah 2020) masih terdapat kesenjangan antara siswa di wilayah perkotaan dengan siswa wilayah pedesaan. (Umar \& Mochamad Nursalim, 2020).

Selama wabah covid-19 masuk ke Indonesia, ada beberapa peraturan pemerintah yang diterbitkan guna untuk pencegahan penyebaran wabah tersebut. Salah satu yang digalakkan adalah adanya social distancing.

Dipublikasikan Oleh :

UPT Publikasi dan Pengelolaan Jurnal

Universitas Islam Kalimantan Muhammad Arsyad Al-Banjari Banjarmasin 
Social distancing merupakan upaya jaga jarak, misalnya seperti menghindari kerumunan, dan kontak fisik. Adanya social distancing tersebut sudah jelas sangat berpengaruh pada dunia pendidikan. Pembelajaran yang dilakukan di sekolah telah diliburkan mulai bulan Maret 2020. Bahkan hingga bulan Mei 2020 saat inipun pembelajaran masih dilakukan dari rumah masing-masing. Sesuai dengan Undang-Undang Kekarantinaan Kesehatan Pasal 59 Ayat 3 tahun 2020 menjelaskan bahwa "pembatasan sosial berskala besar ini paling sedikit meliputi peliburan sekolah dan tempat kerja, pembatasan kegiatan keagamaan, dan atau pembatasan kegiatan di tempat atau fasilitas umum." (Handarini \& Wulandari, 2020).

Sebanyak $81,8 \%$ mengalami kesulitan dalam pelaksanaan kegiatan pembelajaran selama masa pandemi dan sebanyak $18,2 \%$ tidak mengalami kesulitan dalam pelaksanaan kegiatan pembelajaran selama pandemi. $81 \%$ guru selalu mengalami hambatan mengenai media pembelajaran yang digunakan selama pembelajaran daring. $64,16 \%$ guru sering mengalami hambatan hambatan dalam menentukan sikap dalam pembelajaran daring. $64,20 \%$ guru sering mengalami hambatan untuk meningkatkan motivasi belajar siswa dalam pembelajaran daring. $61 \%$ guru sering mengalami hambatan untuk mengembangkan kreatifitas selama pembelajaran daring. $70 \%$ guru sering mengalami hambatan mengenai sarana dan prasarana yang digunakan selama pembelajaran daring. Disarankan supaya guru pendidikan jasmani generasi 80-an dapat meningkatkan keterampilan dalam menggunakan media pembelajaran sehingga proses pembelajaran daring dapat berlangsung dengan baik. (Nopiyanto, 2020).

Menurut Agus, dkk dalam penelitiannya yang berjudul "Studi Eksploratif Dampak Pandemi Covid-19 Terhadap Proses Pembelajaran Online di Sekolah Dasar" dampak covid-19 siswa, orang tua dan guru itu sendiri. Beberapa dampak yang dirasakan murid yaitu murid belum ada budaya belajar jarak jauh karena selama ini sistem belajar dilaksanakan adalah melalui tatap muka, murid terbiasa berada di sekolah untuk berinteraksi dengan teman-temannya, bermain dan bercanda gurau dengan teman-temannya serta bertatap muka dengan para gurunya, dengan adanya metode pembelajaran jarah jauh membuat para murid perlu waktu untuk beradaptasi dan mereka menghadapi perubahan baru yang secara tidak langsung akan mempengaruhi daya serap belajar mereka. Dampak terhadap orang tua yaitu kendala yang dihadapi para orang tua adalah adanya penambahan biaya pembelian kuota internet bertambah, teknologi online memerlukan koneksi jaringan ke internet dan kuota oleh karena itu tingkat penggunaaan kuota internet akan bertambah dan akan menambah beban pengeluaran orang tua. Dampak yang dirasakan guru yaitu tidak semua mahir menggunakan teknologi internet atau media sosial sebagai sarana pembelajaran. (Magdalena et al., 2020)

Meski dalam kondisi yang serba terbatas karena pandemi covid-19 tetapi masih dapat melakukan pembelajaran dengan cara daring. Hanya hal yang menjadi hambatan adalah orang tua harus menambah waktu untuk mendampingi anak-anak.(Anugrahana, 2020)

Selama pembelajaran dimasa pandemi sebanyak 63,8\% siswa mendapat bantuan khusus dari sekolah dan sebanyak $36,2 \%$ siswa tidak mendapat bantuan khusus dari sekolah selama pembelajaran di masa pandemi. Sebanyak 87\% sudah memiliki media ( gadget ) yang mendukung kegiatan pembelajaran dan sebanyak $13 \%$ belum memiliki media ( gadget) yang mendukung kegiatan pembelajaran. Sebanyak 79,9\% mengungkapkan materi pembelajaran juga disesuaikan dengan kondisi pandemi dan sebanyak $20,1 \%$ mengungkapkan materi pembelajaran tidak disesuaikan dengan kondisi pandemi. Sebanyak 50,5\% mengalami kesulitan dalam hal pengumpulan tugas dan sebanyak 49,5\% mengungkapkan tidak megalami kesulitan dalam hal pengumpulan tugas.

Untuk kesesuaian dalam pemberian nilai sebanyak 83,3\% mengungkapkan tidak ada kesesuaian dalam pemberian nilai selama pandemi dan sebanyak $16,7 \%$ mengungkapkan ada kesesuaian dalam pemberian nilai selama pandemi. Sebanyak 8,3\% mengungkapkan memiliki kesiapan yang sangat baik saat menghadapi pembelajaran di masa pandemi, sebanyak 52,4\% menyatakan memiliki kesiapan yang baik saat menghadapi pembelajaran di masa pandemi dan sebanyak 39,3\% mengungkapkan memiliki kesiapan yang kurang baik saat menghadapi pembelajaran di masa pandemi. Sebanyak 65,3\% menyatakan media yang digunakan sudah efektif selama pembelajaran berlangsung dan sebanyak $34,7 \%$ menyataan media yang digunakan belum efektif selama pembelajaran berlangsung.

Sebanyak 42,0\% menyatakan saat pembelajaran di masa pandemi materi yang disampaikan bisa dipahami dengan baik dan sebanyak 58,0\% menyatakan saat pembelajaran di masa pandemi materi yang disampaikan tidak bisa dipahami dengan baik. Sebanyak 68,7\% mengungkapkan proses pembelajaran selama pandemi sudah dilaksanakan sesuai tujuan dan sebanyak 31,3\% mengungkapkan proses pembelajaran selama pandemi belum dilaksanakan sesuai tujuan.

Sebanyak 77,2\% mengungkapkan adanya perubahan jadwal pembelajaran selama pandemi dan sebanyak 22,8\% mengungkapkan tidak adanya perubahan jadwal pembelajaran selama pandemi. Sebanyak

Dipublikasikan Oleh :

UPT Publikasi dan Pengelolaan Jurnal

Universitas Islam Kalimantan Muhammad Arsyad Al-Banjari Banjarmasin 
76,3\% mengungkapkan ekonomi berpengaruh terhadap pembelajaran selama pandemi dan sebanyak $23,7 \%$ mengungkapkan ekonomi tidak berpengaruh terhadap pembelajaran selama pandemi.

Sebanyak 62,4\% mengungkapkan adanya pemantauan terhadap pelaksanaan pembelajaran selama pandemi dan sebanyak 37,6\% mengungkapkan tidak adanya pemantauan terhadap pelaksanaan pembelajaran selama pandemi. Untuk pelaksanaan pembelajaran selama pandemi sebanyak $7,2 \%$ mengungkapkan pembelajaran selama pandemi berjalan sangat baik, sebanyak 46,9\% mengungkapkan berjalan dengan baik, dan sebanyak 45,9\% mengungkapkan pembelajaran selama pandemi berjalan kurang baik. Sistem pembelajaran daring dengan memanfaatkan platform digital pada jenjang sekolah dasar dan menengah cenderung mengubah wajah pendidikan ke arah yang lebih baik, lebih efektif, dan lebih menyenangkan. Guru pun menjadi semakin inovatif dalam mengemas bahan ajar dan semakin kreatif mengembangkan metode pembelajaran untuk menarik antusisme siswa. Meski demikian, perlu dilakukan penyesuaian kembali dengan beragam kemampuan masingmasing guru, siswa, dan orang tua siswa dalam memberikan fasilitas pembelajaran daring ini, sehingga kendala yang dialami dapat diminimalisir. (Lestari \& Gunawan, 2020)

Pembelajaran daring harus terus dilakukan mengingat belum tuntasnya wabah Covid-19 di Indonesia dan membantu pencegahan penyebaran Covid-19 sehingga sampai saat ini masih belum ditentukan kapan akan masuk sekolah kembali untuk pembelajaran tatap muka. (Dwi et al., 2020)

\section{PENUTUP}

Selama masa pandemi covid-19 pembelajaran PJOK di Sekolah Menengah Pertama yang ada di Provinsi Kepulauan Bangka Belitung dilaksanakan secara daring/online. Pembelajaran secara daring/online ini dirasa sudah baik, karena selama pembelajaran di masa pandemi covid-19 siswa mendapat bantuan khusus dari sekolah, mereka juga sudah memiliki media (gadget) yang mendukung kegiatan pembelajaran, materi pembelajaran juga disesuaikan dengan kondisi pandemi. Guru, siswa, maupun orang tua memiliki kesiapan yang baik saat menghadapi pembelajaran di masa pandemi, mereka menganggap media yang digunakan sudah efektif selama pembelajaran berlangsung dan proses pembelajaran selama pandemi sudah dilaksanakan sesuai tujuan, sehingga adanya pemantauan terhadap pelaksanaan pembelajaran selama pandemi covid-19. Berdasarkan hasil penelitian maka disimpulkan bahwa selama pandemi covid-19 pelaksanaan pembelajaran PJOK Sekolah Menengah Pertama di Provinsi Kepulauan Bangka Belitung dilaksanakan secara daring. Pembelajaran daring selama pandemi covid-19 secara keseluruhan sudah baik. Maka dari itu pembelajaran dapat dilaksanakan secara daring selama kondisi pandemi sampai batas waktu yang ditentukan oleh Pemerintah.

\section{REFERENSI}

Ainur Risalah, W Ibad, L Maghfiroh, M I Azza, S A Cahyani, \& Z A Ulfayati. (2020). Dampak Pandemi Covid19 Terhadap Kegiatan Belajar Mengajar Di MI/SD (Studi KBM Berbasis Daring Bagi Guru dan Siswa). JIEES : Journal of Islamic Education at Elementary School, 1(1), 10-16. https://doi.org/10.47400/jiees.v1i1.5

Anugrahana, A. (2020). Hambatan, Solusi dan Harapan : Pembelajaran Daring Selama Masa Pandemi Covid19 Oleh Guru Sekolah Dasar. 282-289.

Argaheni, N. B. (2020). Sistematik Review: Dampak Perkuliahan Daring Saat Pandemi COVID-19 Terhadap Mahasiswa Indonesia. PLACENTUM: Jurnal Ilmiah Kesehatan Dan Aplikasinya, 8(2), 99. https://doi.org/10.20961/placentum.v8i2.43008

Dwi, B., Amelia, A., Hasanah, U., \& Putra, A. M. (2020). Analisis Keefektifan Pembelajaran Online di Masa Pandemi Covid-19. Jurnal Pendidikan Guru Sekolah Dasar, 2(1), 3.

Dyah Purnama Sari, P. S. (2020). Corona Virus Disease 2019. 19-29.

Ekantini, A. (2020). Efektivitas Pembelajaran Daring pada Mata Pelajaran IPA di Masa Pandemi Covid-19: Studi Komparasi Pembelajaran Luring dan Daring pada Mata Pelajaran IPA SMP. 5(November 2020), 187-193.

Engko, C., \& Usmany, P. (2020). Dampak Pandemi Covid-19 Terhadap Proses Pembelajaran Online. Jurnal Akuntansi, 6(1), 23-38. https://ojs3.unpatti.ac.id/index.php/jak/article/view/2709/2283

Firman. (2020). Dampak Covid-19 terhadap Pembelajaran di Perguruan Tinggi. 2(1), 14-20.

Handarini, O. I., \& Wulandari, S. S. (2020). Pembelajaran Daring Sebagai Upaya Study From Home ( SFH) Selama Pandemi Covid 19 Pembelajaran Daring Sebagai Upaya Study From Home ( SFH ) ... .. 8(1), 496-503.

Handayani, L. (2020). Keuntungan, Kendala dan Solusi Pembelajaran Online Selama Pandemi Covid-19 : Studi Ekploratif di SMPN 3 Bae Kudus Lina Handayani. Jurnal Industrial Engineering and Management Research ( Jiemar ), 1(2), 15-23. https://doi.org/https://doi.org/10.7777/jiemar.v1i2

\section{Dipublikasikan Oleh :}

UPT Publikasi dan Pengelolaan Jurnal

Universitas Islam Kalimantan Muhammad Arsyad Al-Banjari Banjarmasin 
Herliandry, L. D., Nurhasanah, Suban, M. E., \& Heru, K. (2020). Transformasi Media Pembelajaran Pada Masa Pandemi Covid-19. Jurnal Teknologi Pendidikan, 22(1), 65-70. http://journal.unj.ac.id/unj/index.php/jtp

Herlina, \& Suherman, M. (2020). Potensi Pembelajaran Pendidikan Jasmani Olahraga dan Kesehatan ( PJOK ) di Tengah Pandemi Corona Virus Disease ( Covid ) -19 Di Sekolah Dasar. Tadulako Journal Sport Sciences and Physical Education, 0383, 3. https://doi.org/http://jurnal.untad.ac.id/jurnal/index.php/PJKR/index

Lestari, P. S., \& Gunawan. (2020). 栗海军 1 ，刘 泽 2 （1 . Indonesian Journal of Elementary and Childhood Education, 1(2), 67-68.

Magdalena, I., Nokhriyana, A. D., Novita, K., Sipayung, S., Tsania, S., \& Tangerang, U. M. (2020). Dampak covid-19 terhadap implementasi pembelajaran daring di sekolah dasar. 2(3), 323-333. https://doi.org/https://ejournal.stitpn.ac.id/index.php/bintang

Mansyur, A. R. (2020). Dampak COVID-19 Terhadap Dinamika Pembelajaran Di Indonesia. Education and Learning Journal, 1(2), 113. https://doi.org/10.33096/eljour.v1i2.55

Marheni, E., Ridwan, M., Purnomo, E., \& Soniawan, V. (2020). Meningkatkan Gairah Belajar Pendidikan Jasmani Olahraga dan Kesehatan Siswa Pasca Pandemi Covid-. 20(3), 149-158. https://doi.org/https://doi.org/10.24036/sb.0590 10.24036/sb.0590 http://sulben.ppj.unp.ac.id

Mastura, \& Santaria, R. (2020). Dampak Pandemi Covid-19 terhadap Proses Pengajaran bagi Guru dan Siswa Pendahuluan. Jurnal Studi Guru Dan Pembelajaran, 3(2), 289-295. https://ejournal.my.id/jsgp/article/view/293

Nopiyanto, Y. E. (2020). Hambatan Guru Pendidikan Jasmani Generasi 80-an dalam Pembelajaran Daring di Tengah Pandemi Covid-19. 5(September), 139-148.

Pratama, R., \& Mulyati, S. (2020). Pembelajaran Daring dan Luring pada Masa Pandemi Covid-19. 1(2), 4959. https://doi.org/10.30870/gpi.v1i2.9405

Rochman, B., Indahwati, N., \& ... (2020). Identifikasi Keterlaksanaan Pembelajaran PJOK Tingkat SMP Di Masa Pandemi Covid 19 Se-Kabupaten Sidoarjo. Jurnal Ilmiah Mandala Education, 6(1), 257-265. https://doi.org/http://ejournal.mandalanursa.org/index.php/JIME/index

Saleh, A. M. (2020). Problematika Kebijakan Pendidikan Di Tengah Pandemi Dan Dampaknya Terhadap Proses Pembelajaran Di Indonesia. Jurnal Pendidikan, 2(2), 1-5.

Siahaan, M. (2020). Dampak Pandemi Covid-19 Terhadap Dunia Pendidikan. Jurnal Kajian Ilmiah, 1(1), $73-80$. https://doi.org/10.31599/jki.v1i1.265

Syah, R. H. (2020). Dampak Covid-19 pada Pendidikan di Indonesia: Sekolah, Keterampilan, dan Proses Pembelajaran. Jurnal Sosial Dan Budaya Syar-I, 7(5), 396. https://doi.org/10.15408/sjsbs.v7i5.15314

Umar, L. M., \& Mochamad Nursalim. (2020). Studi Kepustakaan Tentang Dampak Wabah Covid-19 Terhadap Kegiatan Belajar Mengajar Pada Siswa Sekolah Dasar. Program Studi Bimbingan Konseling,Fakultas Ilmu Pendidikan, Universitas Negeri Surabaya, 600-609.

Wijayanto, A., Yunis, S., Ari, B., Kurniawan, W., Rahadian, A., Amiq, F., Ika, A., Joan, N., Andrianto, R., \& Baun, A. (2020). Bunga Rampai Strategi Pembelajaran Selama Pandemi COVID - 19.

Dipublikasikan Oleh :

UPT Publikasi dan Pengelolaan Jurnal

Universitas Islam Kalimantan Muhammad Arsyad Al-Banjari Banjarmasin 